(c) American Dairy Science Association, 2004.

\title{
Deacidification by Debaryomyces hansenii of Smear Soft Cheeses Ripened Under Controlled Conditions: Relative Humidity and Temperature Influences
}

\author{
C. Bonaïti, M.-N. Leclercq-Perlat, E. Latrille, and G. Corrieu \\ Unité Mixte de Recherche Génie et Microbiologie des Procédés Alimentaires (UMR G.M.P.A.), \\ F-78 850 Thiverval-Grignon, France
}

\section{ABSTRACT}

Model smear soft cheeses were prepared from pasteurized milk inoculated with Debaryomyces hansenii (304, GMPA) and Brevibacterium aurantiacum (ATCC 9175) under aseptic conditions. Debaryomyces hansenii growth and curd deacidification were studied in relation to ripening chamber temperature and relative humidity (RH). A total of 9 descriptors, mainly based on kinetic data, were defined to represent $D$. hansenii growth (2 descriptors), cheese deacidification (5 descriptors), and cheese ripening (2 descriptors). Regardless of the temperature, when the $\mathrm{RH}$ was $85 \%, D$. hansenii growth was inhibited due to limitation of carbon substrate diffusions; consequently, cheese deacidification did not take place. Debaryomyces hansenii growth was most prolific when the temperature was $16^{\circ} \mathrm{C}$, and the $\mathrm{RH}$ was $95 \%$. Kinetic descriptors of lactate consumption and $\mathrm{pH}$ increase were maximal at $16^{\circ} \mathrm{C}$ and $100 \% \mathrm{RH}$. Under these 2 ripening conditions, on $\mathrm{d} 14$ (packaging) the creamy underrind represented a third of the cheese; however, at the end of ripening (d 42), cheese was too liquid to be sold. Statistical analysis showed that the best ripening conditions to achieve an optimum between deacidification and appearance of cheeses (thickness of the creamy underrind) were $12^{\circ} \mathrm{C}$ and $95 \pm 1 \% \mathrm{RH}$.

(Key words: Debaryomyces hansenii, deacidification, ripening temperature, relative humidity)

Abbreviation key: $\mathbf{C}_{\mathbf{L O}}=$ lactose maximal consumption rate on the rind $\left(\mathrm{mmol} / \mathrm{kg}\right.$ of DM per d), $\mathbf{C}_{\mathbf{L T}}=$ lactate maximal consumption rate on the rind ( $\mathrm{mmol} /$ $\mathrm{kg}$ of DM per d), $\mathbf{D}_{\mathbf{L O}}=$ lactose maximal decreasing rate in the core $\left(\mathrm{mmol} / \mathrm{kg}\right.$ of DM per d), $\mathbf{D}_{\mathbf{L T}}=$ lactate maximal decreasing rate in the core $(\mathrm{mmol} / \mathrm{kg}$ of $\mathrm{DM}$ per d), $\mathbf{L}_{\mathbf{H} 2 \mathbf{O}}=$ relative weight loss $(\%), \mathbf{R H}=$ relative humidity (\%), $\mathbf{T}_{\mathbf{U}-\mathbf{R I N D}}=$ thickness of underrind on day

Received April 6, 2004.

Accepted July 20, 2004.

Corresponding author: M.-N. Leclercq-Perlat; e-mail: perlat@ grignon.inra.fr. $14(\mathrm{~mm}), \mu_{\max }=$ maximum growth rate of $D$. hansenii $\left(\right.$ per d), $\mathbf{V}_{\max }=$ maximal rate of deacidification $(\mathrm{pH}$ unit/d), $\mathbf{X}_{\max }=$ mean yeast maximum concentration (yeasts/g of DM).

\section{INTRODUCTION}

Many microbiological and physicochemical parameters affect the ripening of soft bacterial surface-ripened cheeses (e.g., type Munster) (Reps, 1993). Cheese quality depends on the simultaneous control of the raw milk, the lactic acid bacteria and ripening starters, the cheese making technology, the human handling, and the ripening conditions (Leclercq-Perlat et al., 2000). Cheese quality, like smear evolution, depends on ripening chamber factors such as relative humidity (RH), temperature, and atmospheric elements (Ramet, 2000).

The microorganisms present in the smear come from raw milk, lactic acid bacteria and ripened microorganism starters, brine baths and massaging solutions, ambient atmospheric conditions, and cheese making equipment and cheese makers. Various studies have determined the microbiological composition of the smear (Bhowmik and Marth, 1990; Eliskases-Lechner and Ginzinger, 1995a, b; Corsetti et al., 2001; Wouters et al., 2002; Bockelmann, 2002b), which is usually composed of yeasts and bacteria. In modern cheese plants, to ensure the best quality control, these microorganisms mainly come from starters.

Yeasts can survive a $\mathrm{pH}$ as low as 4.0 to 5.0 (Guéguen and Schmidt, 1992), low temperatures $\left(8\right.$ to $\left.12^{\circ} \mathrm{C}\right)$ (Deiana et al., 1984; Fleet, 1990b; Seiler and Busse, 1990; Abadias et al., 2001; Cosentino et al., 2001), and high salt concentrations ( $>4 \%$ ) (Leon-Gonzalez et al., 2000; Cosentino et al., 2001). Depending on their metabolic activities, yeasts may have a positive effect (curd deacidification) (Lecocq and Guéguen, 1994) or a negative one on ripening (causing spoilage or unpleasant taste) (Fleet, 1990a; Jakobsen and Narvhus, 1996). They may also contribute to the ripening process by inhibiting undesired microorganisms (Devoyod, 1990) and by their proteolytic (Besancon et al., 1995) and 
lipolytic activities (Choisy et al., 1997). The development of the bacterial flora on the cheese surface has been shown to be dependent on the metabolism of lactate by yeast (Leclercq-Perlat et al., 1999). This breakdown of lactate and the formation of alkaline metabolites by yeasts increase $\mathrm{pH}$, which enables the growth of less acid-tolerant coryneform bacteria like Brevibacterium linens (Seiler and Busse, 1990; EliskasesLechner and Ginzinger, 1995a; Rattray and Fox, 1999). Furthermore, the production of growth factors by yeasts appears to promote the growth and development of the bacterial flora (Valdes-Stauber et al., 1996). The curd deacidification contributes to modifications of texture (Vassal et al., 1986), to increases in enzymatic activities (Lenoir et al., 1985), and to changes in mineral distribution throughout the cheese (Le Graët and Brûlé, 1988).

Debaryomyces hansenii is generally the predominant yeast in the smear of bacterial surface-ripened cheeses such as Munster (Eliskases-Lechner and Ginzinger, 1995a and b; Roostita and Fleet, 1996; Bockelmann, 1997; Bockelmann, 2002a; Petersen et al., 2002). It is a highly heterogeneous species because of its ability to assimilate different carbon sources (Seiler and Busse, 1990; Nakase et al., 1998; Seiler and Kummerle, 1998; van den Tempel and Jakobsen, 2000; Petersen et al., 2002). It also consumes lactate and lactose at the same time, confirmed on a synthetic medium by Soulignac (1995) and on the surface of model smear cheeses by Leclercq-Perlat et al. (1999). According to Soulignac (1995), D. hansenii exhibited the fastest and best deacidification of curd. During the ripening of cheese inoculated with $D$. hansenii, Leclercq-Perlat et al. (1999) showed that deacidification started when there was no lactose in the cheese rind (d 6) and was correlated with the lactate concentration of the cheese rind and core. The deacidification rate was highest from $\mathrm{d} 7$ to 13 (when the lactose concentration in the core was negligible). However, both Barnett et al. (1990) and Petersen et al. (2002) have shown that $D$. hansenii strains varied in their ability to grow on lactate and exhibited differences in $\mathrm{pH}$ and $\mathrm{NaCl}$ tolerances, and that the dominant strain found in brine baths was better adapted than other strains to the environmental conditions existing on surface-ripened cheeses during production (lactate as the main carbon source, $\mathrm{pH}$ ranging from 5.5 to 6.0 and $\mathrm{NaCl}$ concentrations of 7 to $10 \%$ [wt/vol]).

van den Tempel and Jakobsen (2000) have described some of the enzymatic properties of $D$. hansenii strains: they were not very lipolytic and did not release free fatty acids from milk fat at $10^{\circ} \mathrm{C}$. Their lipase activities were not significant. In addition, they were not able to hydrolyze casein at $10^{\circ} \mathrm{C}$. They did not have any exopeptidase activities, but they exhibited some endopeptidase ones (Schmidt et al., 1979; Klein et al., 2002). Consequently, the proteolytic activity of $D$. hansenii was low.

Environmental factors (ripening temperature, $\mathrm{RH}$ of ripening chamber) play a determining role in microbial development and the enzymatic process (van den Tempel and Jakobsen, 2000). Soft cheese ripening temperature usually varies between $8^{\circ} \mathrm{C}$ (Epoisses) and $16^{\circ} \mathrm{C}$ (Reblochon), but many French soft cheeses are ripened at $12^{\circ} \mathrm{C}$. Increasing the ripening temperature $(3$ to $4^{\circ} \mathrm{C}$ ) is one of the easiest and most economically feasible ways to accelerate ripening (Nunez et al., 1991). However, the influence of ripening temperature on cheese qualities depends on the microbial group or the enzymatic process (Lenoir et al., 1985). Soft cheeses which have high enzymatic activities in the surface microflora can withstand important temperature increases without significant alteration to cheese quality (texture, unpleasant taste) (Reps, 1993; Ramet, 2000).

The $\mathrm{RH}$ influences both the total water content of the cheese and water activity on its surface (Fox et al., 1993; Reps, 1993; Hardy et al., 2000). The cheeses are always ripened at a $\mathrm{RH}$ of less than $100 \%$ (saturation point). The chamber $\mathrm{RH}$ is selected according to the type of cheeses; for smear soft cheeses it usually varies between 95 to $98 \%$, and for mold soft cheeses it varies between 90 to $95 \%$ (Lesage-Meessen and Cahagnier, 1998). When the $\mathrm{RH}$ is $<100 \%$, the cheese water evaporates into the atmosphere. This water loss is related to different cheese parameters (initial water quantity, specific surface, bound water quantity, and surface density) (Reps, 1993; Hardy et al., 2000). Regardless of the ripened soft cheese, it is generally thought that the total water weight loss varies during ripening between 10 to $15 \%$ of the initial weight. It is equally thought that the $\mathrm{RH}$ inhibits more undesirable microorganism growth than ripening microorganism growth.

The aim of this study was 2 -fold. First, $D$. hansenii development on the rind was examined during ripening, in relation to temperature and $\mathrm{RH}$ of the ripening chamber. Second, the cheese deacidification and its consequences for underrind thickness were investigated in association with $D$. hansenii growth and carbon metabolism evolution in the cheeses.

\section{MATERIALS AND METHODS}

\section{Biological Material}

Debaryomyces hansenii (GMPA, 304), which has interesting technological properties (Leclercq-Perlat et al., 1999), and Brevibacterium aurantiacum (ATCC 
9175; Gavrish et al., 2004) were used as ripening cultures.

Preparation of Debaryomyces hansenii and Brevibacterium aurantiacum cultures. The preparations of $D$. hansenii and $B$. aurantiacum were carried out as previously described by Leclercq-Perlat et al. $(1999 ; 2000)$. At 1 wk before the cheese-making test, one tube of each strain was sampled and its viable cell count was determined. Surface plate counting was carried out on a chloramphenicol yeast extract glucose agar after incubation for $2 \mathrm{~d}$ at $25^{\circ} \mathrm{C}$ to prevent bacterial growth and on an amphotericin lactate-based medium (Piton, 1988) after incubation for at least $7 \mathrm{~d}$ at $25^{\circ} \mathrm{C}$ to prevent the growth of yeasts and mold.

Lactic acid bacteria culture. The mesophilic lactic acid bacteria used was a lyophilized Flora Danica culture (CHN11; Chr Hansen, Arpajon, France). This culture $(1 \mathrm{~g})$ was mixed with sterile skim milk $(50 \mathrm{~mL}$ reconstituted at $10 \%)$ containing glycerol ( $5 \% \mathrm{vol} / \mathrm{vol})$ as cryo-protector. This mixture was then transferred to $10-\mathrm{mL}$ tubes and stored at $-80^{\circ} \mathrm{C}$. Before each cheese-making trial one aliquot of the lactic acid bacteria starter was cultured at $22^{\circ} \mathrm{C}$ in $1.5 \mathrm{~L}$ of sterile skim milk for $16 \mathrm{~h}$.

\section{Cheese Making}

The cheeses were prepared on a pilot scale under aseptic conditions in a sterilized $2-\mathrm{m}^{3}$ chamber where coagulation, cutting, draining, and shaping of the curds were performed. The chamber and all the nonautoclavable equipment were cleaned and sterilized as described previously (Leclercq-Perlat et al., 1999). The cheese-making chamber temperature was maintained at $28 \pm 1^{\circ} \mathrm{C}$.

For each cheese-making trial, $100 \mathrm{~L}$ of milk was used to make 45 cheeses (diameter $=110 \mathrm{~mm}$; thickness $=30$ $\mathrm{mm}$ ). The raw milk was obtained from the experimental farm of the Institut National Agronomique ParisGrignon (Thiverval-Grignon, France) and was standardized at $29 \mathrm{~g} / \mathrm{L}$ of fat by mixing skim and full-cream milk. The milk contained $>32 \mathrm{~g} / \mathrm{L}$ of protein, and its microbiological quality was $<10^{5} \mathrm{cfu} / \mathrm{mL}$ (on MRS, M17, YEGC, and BHI; these counts were not the same on all media) before pasteurization. After mixing, the milk was pasteurized at $75 \pm 1^{\circ} \mathrm{C}$ for $30 \mathrm{~s}$ and then cooled to the incubation temperature $\left(34 \pm 1^{\circ} \mathrm{C}\right)$. Milk $\mathrm{pH}$ varied from 6.5 to 6.6. The first liter of milk poured into the coagulation tank was considered to be time zero of the cheese making. At that point it was inoculated with the lactic starter $(1.5 \% \mathrm{vol} / \mathrm{vol})$ and the ripening starters. After pasteurization of all the milk, the concentrations of $D$. hansenii and Brevibacterium aurantiacum were $10^{4} \mathrm{cfu} / \mathrm{mL}$ and $10^{6} \mathrm{cfu} / \mathrm{mL}$, respec- tively. Because of the lactic bacteria activity, the milk $\mathrm{pH}$ reached 6.3 after 80 to $110 \mathrm{~min}$. Then the coagulant (rennet containing $520 \mathrm{mg} / \mathrm{L}$ of chymosin; Degussa, Beaune, France) was added ( $30 \mathrm{~mL} / 100 \mathrm{~L})$. The coagulation time was approximately $15 \mathrm{~min}$, and the curd was cut into cubes after 40 min of hardening. Around $40 \mathrm{~L}$ of whey were drained after $40 \mathrm{~min}$ to obtain a cheese DM between 40 and $42 \%$. It was shaped in polyurethane molds (diameter, $110 \mathrm{~mm}$; height, 77 $\mathrm{mm}$ ), producing cheeses weighing around $280 \mathrm{~g}$. The molds were inverted twice, after $30 \mathrm{~min}$ and $5 \mathrm{~h}$. At 3 $\mathrm{h}$ after molding, the temperature of the cheese-making chamber was reduced to 20 to $22^{\circ} \mathrm{C}$. At $24 \mathrm{~h}$ after molding, the cheeses were plunged into sterile brine (330 $\mathrm{g}$ of $\mathrm{NaCl} / \mathrm{L}$ at $\mathrm{pH} 5.5$ ) for $25 \mathrm{~min}$ at $14 \pm 1^{\circ} \mathrm{C}$. Then they were transferred to the ripening chamber that had been sterilized with peracetic acid. On $d 1$, they were maintained at $12^{\circ} \mathrm{C}$ and $85 \% \mathrm{RH}$. From d 2 until $\mathrm{d} 14$, they were kept at a defined temperature (8 $\pm 1,12 \pm 1$, or $\left.16 \pm 1^{\circ} \mathrm{C}\right)$ and a defined $\mathrm{RH}(85 \pm 1,93$ \pm 2 , or $100 \%$ ) with a continuous airflow that renewed total air volume every $2 \mathrm{~h}$. On d 6, the cheeses were turned. On $\mathrm{d} 14$, the temperature and $\mathrm{RH}$ were changed to $12^{\circ} \mathrm{C}$ and $85 \pm 1 \% \mathrm{RH}$. The cheeses were wrapped on $\mathrm{d} 15$ and ripened at $4^{\circ} \mathrm{C}$ until d 42 . Their $\mathrm{RH}$ was unknown after wrapping. A cheese was removed on a daily basis for analysis between $\mathrm{d} 2$ and 15. A cheese was examined every 4 or $5 \mathrm{~d}$ between $\mathrm{d}$ 15 and 42 .

\section{Analyses Performed on the Cheeses}

The rind ( $1 \mathrm{~mm}$ of height on all cheese surfaces) and core of each cheese were separated by the method described by Le Graët and Brûlé (1988) and then analyzed. Half the cheese was used to prepare the suspensions as previously described (Leclercq-Perlat et al., 1999, 2000). Viable cell counts of $D$. hansenii and of B. aurantiacum were measured only in the cheese rind because these microorganisms grow only on the surface under strict aerobic conditions (Ferchichi et al., 1986; Gripon, 1993; Leclercq-Perlat et al., 2000). The viable cell concentrations of $D$. hansenii and $B$. aurantiacum were determined for the cheese suspension as previously described (Leclercq-Perlat et al., 2000). The total concentration of $D$. hansenii 304 in cheese suspensions was determined using a Coulter counter (model Z2; Beckman-Coultronics, Margency, France) according to Leclercq-Perlat et al. (1995). For each sample the equivalent diameter $\left(\mathrm{d}_{\mathrm{i}}\right)$ and number of particles per $\mathrm{mL}$ of suspension were analyzed to obtain a distribution histogram between $d_{i}$ and $d_{i+1}(\mu \mathrm{m})$. Three determinations per sample were carried out. 
Table 1. Left: Presentation of the 2-factor, 3-level complete factorial experimental design $\left(3^{2}\right)$. Right: Values of kinetic descriptors obtained for each temperature $(\theta)$ and relative humidity $(\mathrm{RH})$ used during cheese deacidification by Debaryomyces hansenii.

\begin{tabular}{|c|c|c|c|c|c|c|c|c|c|c|c|}
\hline Run & $\theta$ & $\mathrm{RH}$ & $\mu_{\max }^{1}$ & $\mathrm{X}_{\max }^{2}$ & $\mathrm{C}_{\mathrm{LO}}{ }^{3}$ & $\mathrm{D}_{\mathrm{LO}}{ }^{4}$ & $\mathrm{C}_{\mathrm{LT}}^{5}$ & $\mathrm{D}_{\mathrm{LT}}^{6}$ & $\mathrm{~V}_{\max }{ }^{7}$ & $\mathrm{~L}_{\mathrm{H} 2 \mathrm{O}}^{8}$ & $\mathrm{~T}_{\mathrm{U}-\mathrm{RIND}}{ }^{9}$ \\
\hline & & & $(/ \mathrm{d})$ & $\begin{array}{l}\text { (yeasts/g } \\
\text { of } \mathrm{DM} \text { ) }\end{array}$ & \multicolumn{4}{|c|}{ - $(\mathrm{mmol} / \mathrm{kg}$ of DM per $\mathrm{d})-$} & $\begin{array}{l}\text { (pH } \\
\text { unit/d) }\end{array}$ & $(\%)$ & $(\mathrm{mm})$ \\
\hline 1 & 8 & 85 & 0.16 & 2.47 & 15.90 & 4.91 & 13.37 & 9.55 & 0.12 & 26 & 0 \\
\hline 2 & 8 & 93 & 0.23 & 7.76 & 15.13 & 8.59 & 19.55 & 22.62 & 0.16 & 18 & 1.5 \\
\hline 3 & 8 & 100 & 0.20 & 6.03 & 21.51 & 5.97 & 22.83 & 20.80 & 0.18 & 10 & 2 \\
\hline 4 & 12 & 85 & 0.24 & 4.73 & 19.20 & 5.01 & 20.18 & 9.63 & 0.13 & 25 & 1 \\
\hline 5 & 12 & 93 & 0.36 & 7.17 & 18.08 & 10.42 & 16.16 & 17.88 & 0.24 & 11 & 2.5 \\
\hline 6 & 12 & 93 & 0.34 & 7.47 & 18.73 & 8.50 & 15.17 & 20.62 & 0.22 & 12 & 2.5 \\
\hline \multicolumn{12}{|l|}{ Average } \\
\hline $5 \& 6$ & 12 & 93 & 0.35 & 7.32 & 18.41 & 9.46 & 15.67 & 19.25 & 0.23 & 11.5 & 2.5 \\
\hline 7 & 12 & 100 & 0.37 & 8.53 & 26.62 & 7.26 & 26.92 & 20.49 & 0.20 & 18 & 3 \\
\hline 8 & 16 & 85 & 0.25 & 6.50 & 20.50 & 8.07 & 8.14 & 14.71 & 0.21 & 30 & 0.5 \\
\hline 9 & 16 & 93 & 0.41 & 9.18 & 19.99 & 8.81 & 18.98 & 20.04 & 0.27 & 22 & 2 \\
\hline 10 & 16 & 100 & 0.34 & 6.56 & 30.09 & 14.94 & 33.65 & 35.79 & 0.33 & 16 & 4 \\
\hline \multicolumn{12}{|c|}{${ }^{1} \mu_{\max }=$ maximum growth rate of $D$. hansenii $(/ \mathrm{d})$} \\
\hline \multicolumn{12}{|c|}{${ }^{2} \mathrm{X}_{\max }=$ Mean yeast maximum concentration (yeasts/g of DM). } \\
\hline \multicolumn{12}{|c|}{${ }^{3} \mathrm{C}_{\mathrm{LO}}=$ Lactose maximal consumption rate on the rind ( $\mathrm{mmol} / \mathrm{kg}$ of $\mathrm{DM}$ per $\left.\mathrm{d}\right)$. } \\
\hline \multicolumn{12}{|c|}{${ }^{4} \mathrm{D}_{\mathrm{LO}}=$ Lactose maximal decreasing rate in the core $(\mathrm{mmol} / \mathrm{kg}$ of $\mathrm{DM}$ per $\mathrm{d})$} \\
\hline \multicolumn{12}{|c|}{${ }^{5} \mathrm{C}_{\mathrm{LT}}=$ Lactate maximal consumption rate on the rind $(\mathrm{mmol} / \mathrm{kg}$ of $\mathrm{DM}$ per $\mathrm{d})$. } \\
\hline \multicolumn{12}{|c|}{${ }^{6} \mathrm{D}_{\mathrm{LT}}=$ Lactate maximal decreasing rate in the core $(\mathrm{mmol} / \mathrm{kg}$ of $\mathrm{DM}$ per $\mathrm{d})$} \\
\hline \multicolumn{12}{|c|}{${ }^{7} \mathrm{~V}_{\max }=$ Maximal rate of deacidification $(\mathrm{pH}$ unit/d). } \\
\hline \multicolumn{12}{|c|}{${ }^{8} \mathrm{~L}_{\mathrm{H} 2 \mathrm{O}}=$ Relative weight loss $(\%)$} \\
\hline & & & & & & & & & & & \\
\hline
\end{tabular}

The arithmetic mean of the total concentration and the cell size distribution were calculated.

For each part of the cheeses (rind and core), measurements of $\mathrm{DM}, \mathrm{pH}$, and lactose and lactate concentrations were carried out (Leclercq-Perlat et al., 1999). The thickness of the cheese underrind was measured on the first $10 \mathrm{~mm}$ at 6 points on each face, and the arithmetic average of these 12 measurements was calculated.

Between d 1 and 14, a representative cheese was weighed using an electronic balance (Precisa; XB620C, precision $\pm 0.01 \mathrm{~g}$ ) connected to an automatic acquisition system.

The appearance of the cheese (color of the rind, microorganism cover, and texture appearance of the underrind) was estimated as proposed by Agioux (2003).

\section{Experimental Design}

The effects of temperature and $\mathrm{RH}$ on the cheese deacidification by $D$. hansenii were examined using a 2-factor, 3-level, complete factorial experimental design $\left(3^{2}\right)$. The 9 combinations of temperature and $\mathrm{RH}$ are shown in Table 1 (left part). The levels of $\mathrm{RH}$ were 85,93 , and $100 \%$ and of temperature were 8,12 , and $16^{\circ} \mathrm{C}$. Levels were chosen in accordance with those of interest during the ripening of smear cheeses. The trial corresponding to the central point of the experimental design was duplicated (runs 5 and 6; Table 1).

\section{Statistical Analysis}

The utilization of lactose, lactate, and D. hansenii, as well as the cheese appearance and $\mathrm{pH}$ during ripening, were described by 1 or 2 descriptors for each deacidification parameter. Except for $\mathrm{pH}$, these descriptors were calculated by using linear regression using Stagraphics Plus Software (Statistical Graphics Corp.). The $\mathrm{pH}$ descriptor (maximal deacidification rate) $\left(\mathbf{V}_{\max }\right)$ was determined by a Weibull model (Schepers et al., 2000). The general linear model (GLM) procedure (Statgraphics Plus Software) was used to calculate quadratic models as well as to determine the influence of the 2 factors (temperature and $\mathrm{RH}$ ) on the deacidification parameters. The nonsignificant terms were omitted one by one, using the procedure Stepwise Backwards (Statgraphics Software); consequently, only the terms significant at a $95 \%$ confidence level $(P$ $<0.05$ ) were considered. The 3 -dimensional response surfaces of each descriptor vs. temperature and $\mathrm{RH}$ were plotted to illustrate the main and interactive effects. These effects were linear, quadratic, or interactive.

\section{RESULTS}

Regardless of the trial, the DM of the rind increased from $44 \pm 1 \%$ to $47 \pm 1 \mathrm{~g}$ dry cheese/100 $\mathrm{g}$ of cheese during cheese ripening. The DM was slightly lower in 


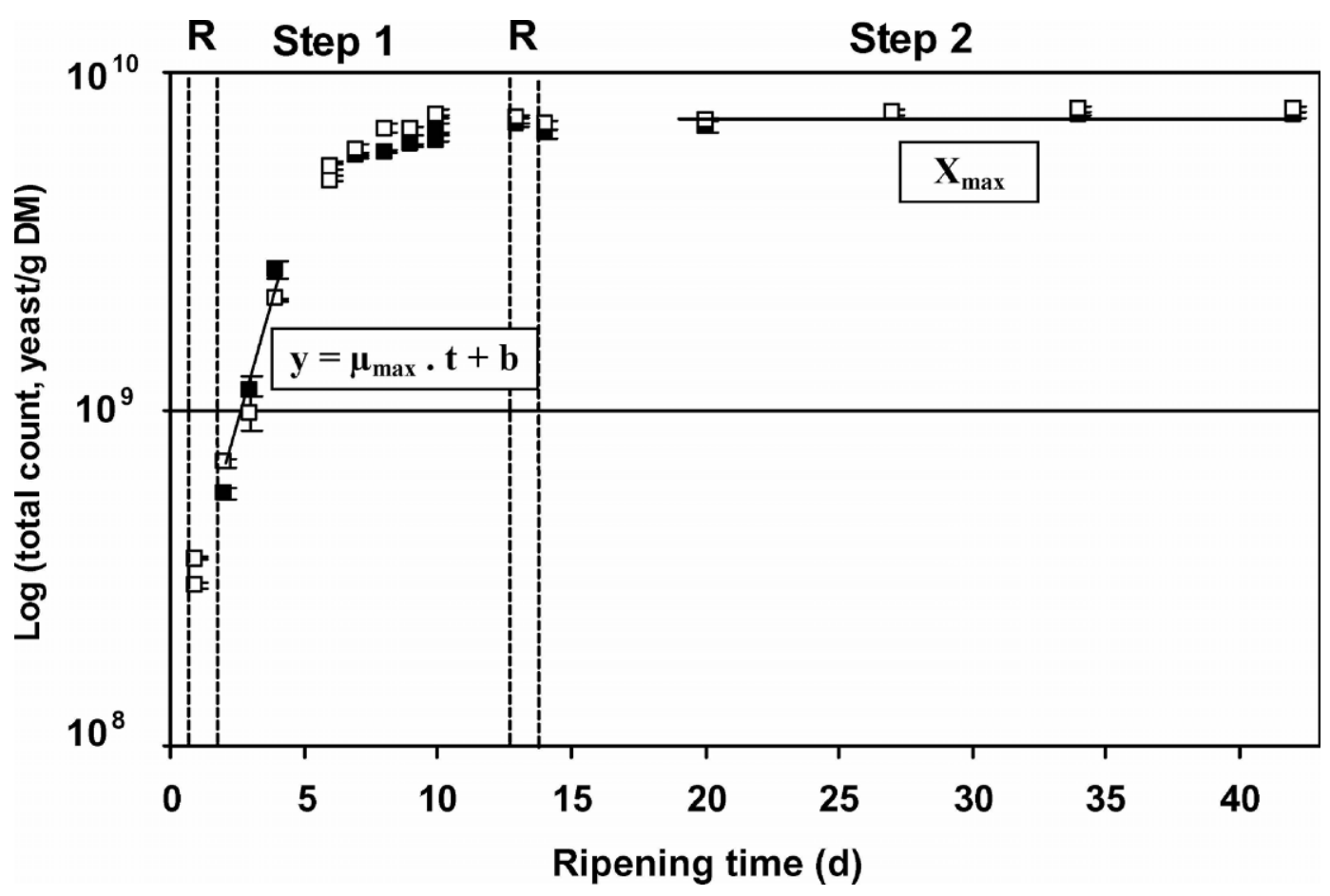

Figure 1. Total counts of Debaryomyces hansenii in the rind of a bacterial surface-ripened soft cheese in relation to ripening time (d 42) and its 2 descriptors: maximum growth rate of $D$. hansenii $\left(\mu_{\max }\right)$ and mean yeast maximum concentration $\left(\mathrm{X}_{\max }\right)$. Step 1: Chamber ripening at $12^{\circ} \mathrm{C}$ and relative humidity $(\mathrm{RH})$ of $93 \%$. Step 2: Ripening under packaging at $4^{\circ} \mathrm{C}(\mathrm{RH}$ unknown). $\mathrm{R}=$ surface drying period $(24 \mathrm{~h}$ at $12^{\circ} \mathrm{C}$ and $85 \% \square=\operatorname{run} 5 ; \square=\operatorname{run} 6$.

the core than in the rind but showed the same evolution, reaching $43 \pm 1 \%$ at the end of ripening.

To avoid the effect of DM variation, the microbiological, biochemical, and physicochemical measurements were expressed in relation to DM, even though microbiological growth took place in the water phase.

\section{Description of Phenomena Observed at $12^{\circ} \mathrm{C}$ and $93 \% \mathrm{RH}$}

Growth of Debaryomyces hansenii. Figure 1 shows the evolution of $D$. hansenii (yeasts/g of DM) in the rind during ripening for the 2 center point trials (runs 5 and 6). Three phases of the growth time were distinguished (Figure 1), as previously described by Leclercq-Perlat et al. (1999) using the same conditions of ripening. The maximum specific growth rate $\left(\mu_{\max }\right)$ during the exponential phase was determined by linear regression between $\mathrm{d} 2$ and 4 . Regardless of the trial, $\mu_{\max }$ was equal to $0.35 \pm 0.06$ per $\mathrm{d}$ (Table 1 , right part, average of trials 5 and 6 ) and associated generation time was close to $2 \mathrm{~d}$. On $\mathrm{d} 5$, the total yeast count was greater than $2 \times 10^{9}$ yeasts/g of DM. Between d 6 and 10,D. hansenii growth was slower than the first exponential phase, decelerating gradually and reaching $7 \times 10^{9}$ yeasts/g of $\mathrm{DM}$ on $\mathrm{d} 10$.
Between d 14 and 42, whatever the run, the mean yeast count remained constant, close to $7.3 \times 10^{9}$ yeast/ $\mathrm{g}$ of DM. The average of these counts was used to determine the total concentration $\left(\mathbf{X}_{\mathbf{m a x}}\right)$.

Viable cell counts in relation to ripening time (data not shown) followed the same evolution as the total yeast counts. While inoculation level was constant, total cell count was greater than viable cell count (close to $6.3 \times 10^{7} \mathrm{cfu} / \mathrm{g}$ of $\left.\mathrm{DM}\right)$.

Evolution of lactose and lactate concentrations. Figure 2 shows the evolutions of lactose and lactate concentrations ( $\mathrm{mmol} / \mathrm{g}$ of DM) in the rind and in the core during ripening for runs 5 and 6.

Lactose concentrations decreased quickly, regardless of where the cheese was sampled (Figure 2). Lactose was quickly assimilated on the cheese rind, with a maximal consumption rate $\left(\mathbf{C}_{\mathbf{L O}}\right)$, determined by a linear regression between $\mathrm{d} 1$ and 4 . Mean $\mathrm{C}_{\mathrm{LO}}$ of runs 5 and 6 was close to $18.4 \mathrm{mmol} / \mathrm{g}$ of DM per d (Table 1). On $d 6$, the lactose concentration in the rind was negligible. It was slightly greater in the core than in the rind, but the overall changes were similar. Lactose concentrations in the cheese core became negligible on d 13. The lactose maximal decreasing rate $\left(\mathbf{D}_{\mathbf{L O}}\right)$ in the core was calculated by linear regression between 


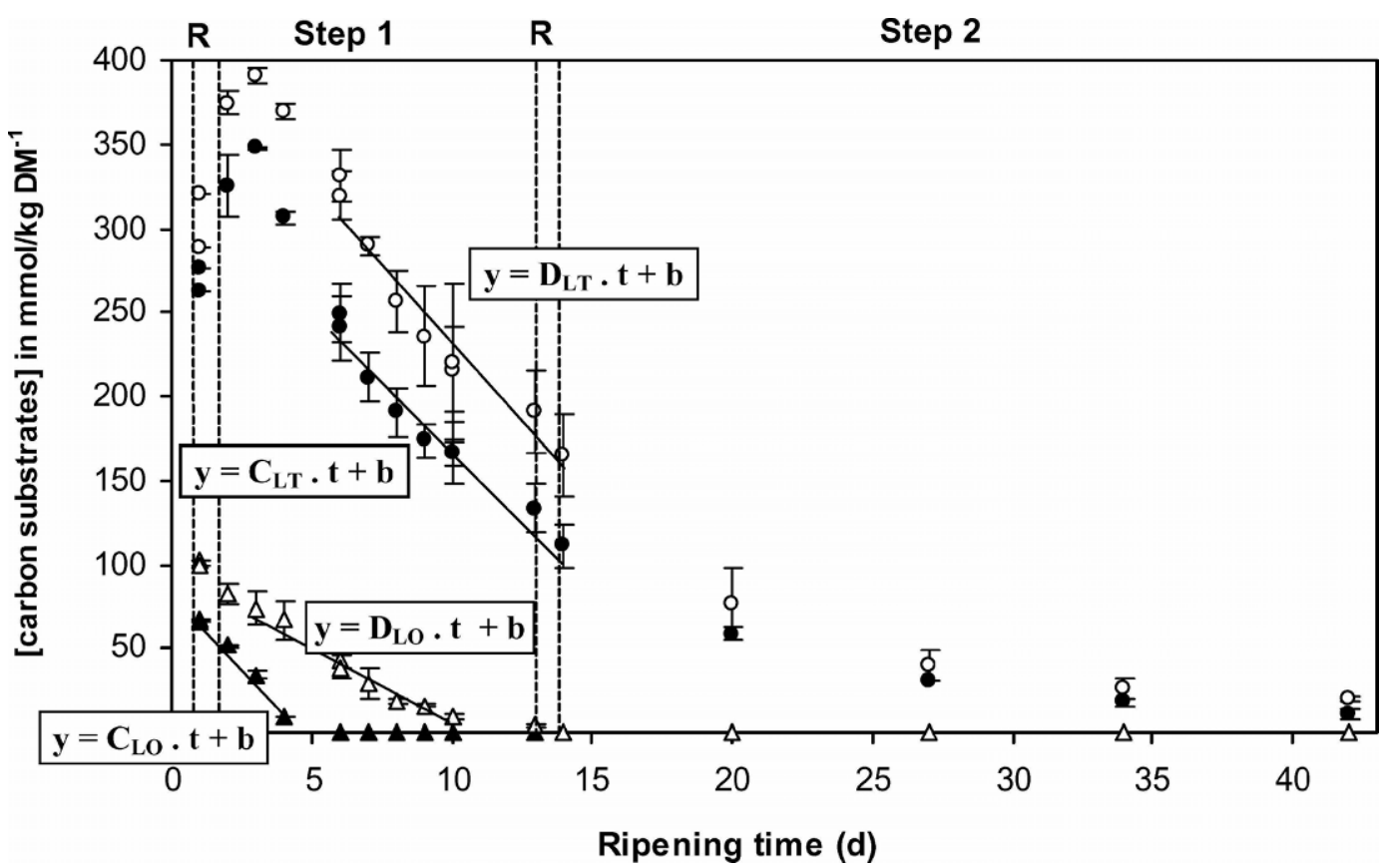

Figure 2. Decrease in the levels of lactose and lactate in the rind and in the core of a bacterial surface-ripened soft cheese in relation to ripening time and determination of their kinetic descriptors: lactose maximal consumption rate on the rind ( $\mathrm{C}_{\mathrm{LO}}$ ), lactose maximal decreasing rate in the core $\left(\mathrm{D}_{\mathrm{LO}}\right)$, lactate maximal consumption rate on the rind $\left(\mathrm{C}_{\mathrm{LT}}\right)$, and lactate maximal decreasing rate in the core $\left(\mathrm{D}_{\mathrm{LT}}\right)$. Step 1: Chamber ripening at $12^{\circ} \mathrm{C}$ and relative humidity $=93 \%$. Step 2: Ripening under packaging at $4^{\circ} \mathrm{C}$. $\mathrm{R}=$ surface drying period $\left(24 \mathrm{~h}\right.$ at $12^{\circ} \mathrm{C}$ and $85 \%$ relative humidity). Each symbol represents the average of runs 5 and 6 . Open symbols represent the carbon substrate concentration in the core; closed symbols represent that in the rind. Lactate $(\bullet, \bigcirc)$ and lactose $(\boldsymbol{\Delta}, \triangle)$.

d 3 to 10 . Whatever the center point considered, it was close to $9.5 \mathrm{mmol} / \mathrm{g}$ of DM per d (Table 1 ).

Lactate concentrations increased in the core and in the rind between $d 1$ and 3 (Figure 2) because of post acidification phenomenon, previously observed by Lenoir et al. (1985) and Leclercq-Perlat et al. (2000). On d 3, lactate concentration was maximal, close to 350 and $400 \mathrm{mmol} / \mathrm{kg}$ of $\mathrm{DM}$ in the rind and in the core, respectively. From d 4 and until d 14 (packaging), it decreased rapidly with a mean maximal rate, calculated by a linear regression to be close to $16 \mathrm{mmol} / \mathrm{g}$ of DM per $\mathrm{d}$ for the rind $\left(\mathbf{C}_{\mathbf{L T}}\right)$ and close to $19 \mathrm{mmol} /$ $\mathrm{g}$ of DM per $\mathrm{d}$ for the core $\left(\mathbf{D}_{\mathbf{L T}}\right)$ between $\mathrm{d} 6$ and 14 (Table 1). On d 14 (packaging), the lactate concentration of the rind reached $110 \mathrm{mmol} / \mathrm{kg}$ of DM. Then, and until the end of ripening, it continued to decrease, but not linearly, and became negligible on d 35. From $\mathrm{d} 4$ to the end of ripening, lactate concentration of the core was slightly greater than that of the rind and did not approach zero until d 42. However, the overall changes were similar.

Evolution of $\mathbf{p H}$. Figure $3 \mathrm{~A}$ shows the $\mathrm{pH}$ changes of the core and of the rind for runs 5 and 6 . Figure 3B is the representation of rind $\mathrm{pH}$ for run 5 after data smoothing out by a Weibull model. The same data were observed for run 6 .
Core $\mathrm{pH}$ changed slowly during ripening (Figure $3 \mathrm{~A})$. On d 1, it was equal to $4.70 \pm 0.02$. From $d 2$ to 6 , it decreased a little ( $0.1 \mathrm{pH}$ unit) because of postacidification phenomena. Then, it increased slightly until the end of ripening, reaching $5.40 \pm 0.04$ on $d 42$.

Between $\mathrm{d} 2$ and 8 , rind $\mathrm{pH}$ presented a large standard deviation (Figure 3A) because of differences of $\mathrm{pH}$ observed for the 2 faces of each cheese.

Irrespective of the trial, 3 general observations can be drawn from the results. First of all, between d 1 and 3, a lag phase took place, and the $\mathrm{pH}$ remained constant at $4.80 \pm 0.06$. Secondly, between $d 4$ and 13, $\mathrm{pH}$ values increased strongly, reaching 6.8 on d 13 . The descriptor selected to explain this rind $\mathrm{pH}$ increase was determined by calculating the Weibull model to obtain the first derivative in relation to time. This mean maximal deacidification rate $\left(\mathrm{V}_{\max }\right)$ was close to $0.23 \mathrm{pH}$ units/d. Thirdly, from d 14 (packaging) to the end of cheese ripening, the rind $\mathrm{pH}$ did not change, remaining close to $7.3 \pm 0.1$.

Evolution of cheese weight. From d 2 to 14, the cheese weight decreased linearly in 2 phases. However, for simplicity, we considered only one linear phase. The relative weight loss (real weight divided by initial weight) was chosen as the descriptor $\left(\mathbf{L}_{\mathbf{H} 2 \mathbf{O}}\right)$. On 14 this loss was close to $11 \%$, regardless of the run 
A

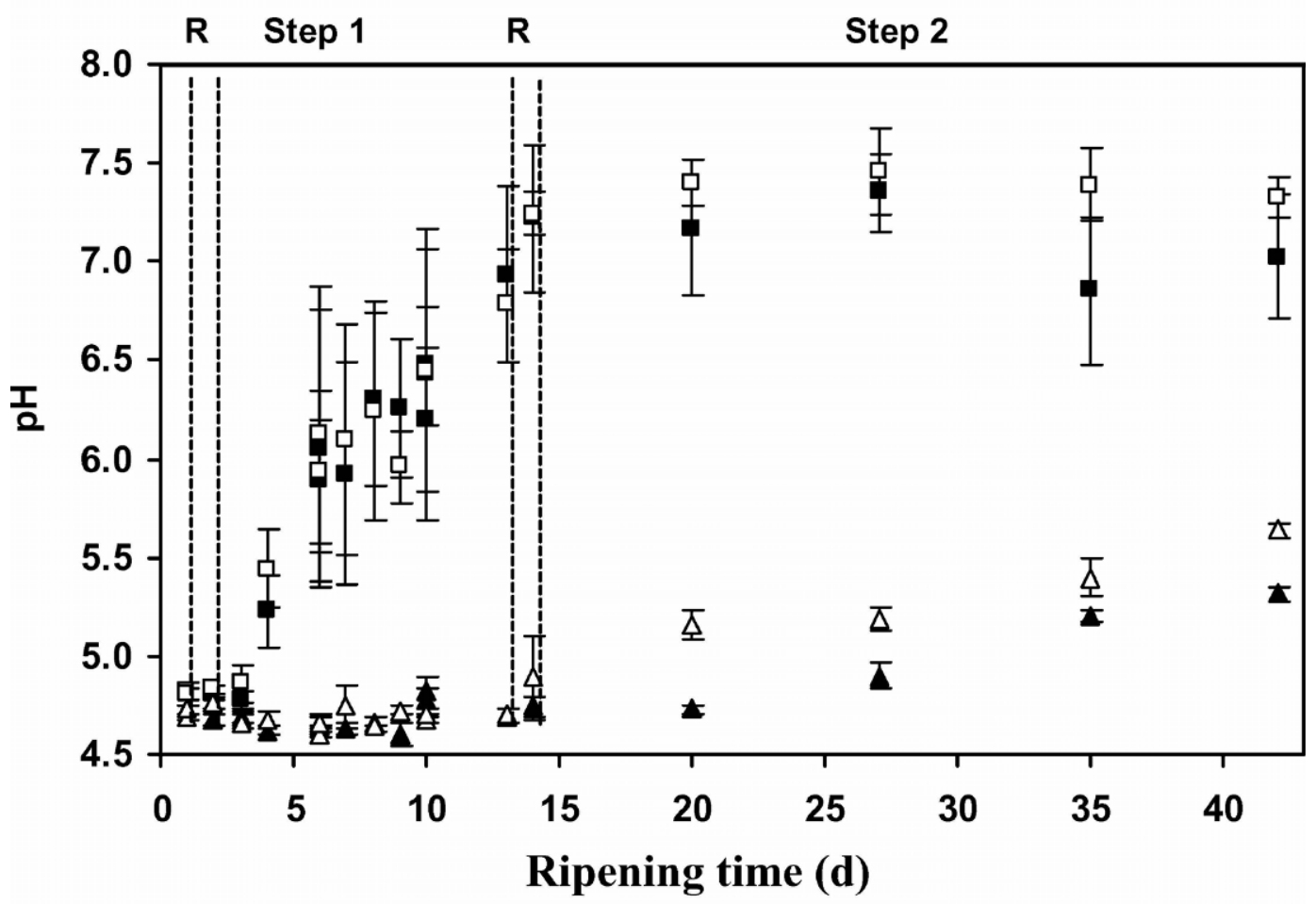

B

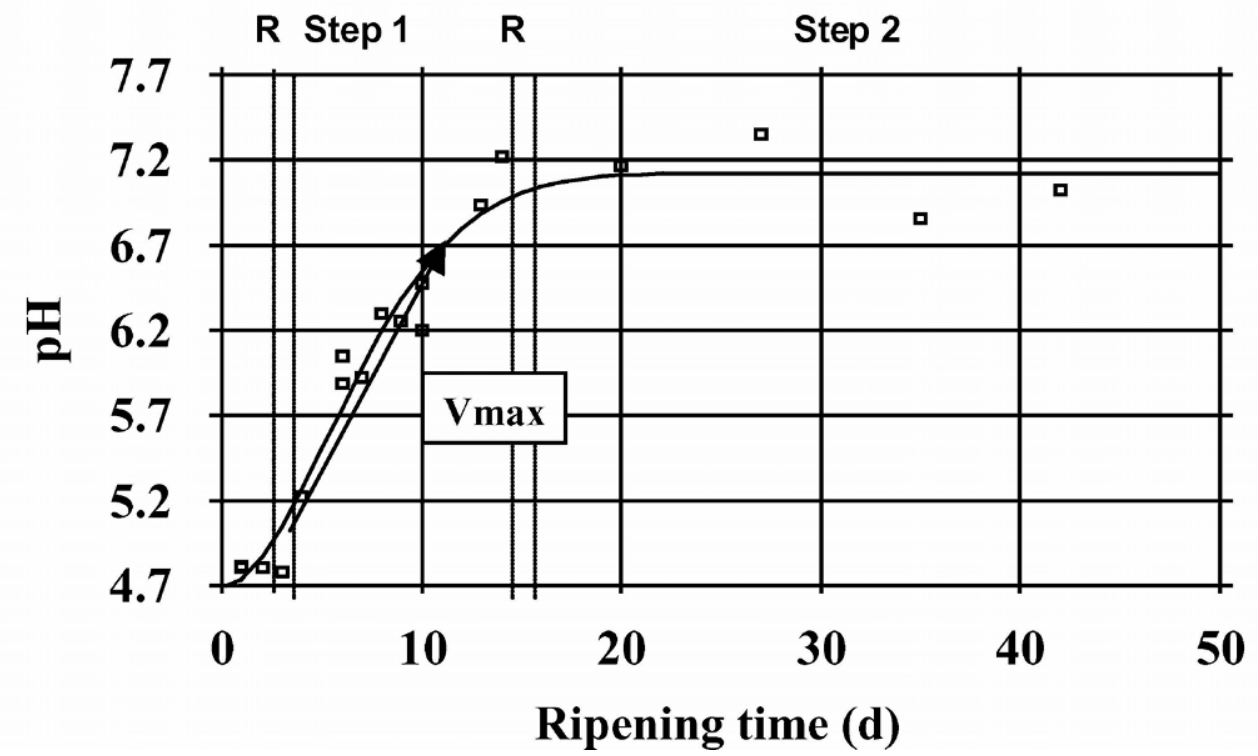

Figure 3. Evolutions of $\mathrm{pH}$ in the rind $(\boldsymbol{\square}, \square)$ and in the core $(\boldsymbol{\Delta}, \triangle)$ of a bacterial surface-ripened soft cheese in relation to ripening time (d 42). Step 1: Chamber ripening at $12^{\circ} \mathrm{C}$ and relative humidity $=93 \%$. Step 2: Ripening under packaging at $4^{\circ} \mathrm{C}$. $\mathrm{R}=\mathrm{surface}$ drying period (24 h at $12^{\circ} \mathrm{C}$ and $85 \%$ relative humidity). A) Experimental evolution; closed symbols ( $\square, \boldsymbol{\Delta}$ ) for run 5 and open ones ( $\square, \triangle$ ) for run 6. B) Rind $\mathrm{pH}$ evolution of run 5 after smoothing out by a Weibull model in relation to ripening time. 
Table 2. Best-fit equations for the effects of temperature and relative humidity on kinetic descriptors during cheese deacidification by Debaryomyces hansenii. $\mathrm{a}=$ all factors of the equations for temperature $\left({ }^{\circ} \mathrm{C}\right)(\theta)$ and relative humidity $(\%)(\mathrm{RH})$ were given with $P<0.05 . \mathrm{R}=$ determination coefficient.

\begin{tabular}{lllll}
\hline Descriptors & Equation $^{\mathrm{a}}$ & $\mathrm{R}^{2}$ & $P$ value & $\mathrm{SE}$ \\
\hline$\mu_{\max }{ }^{1}$ & $-11.4249+0.2440[\mathrm{RH}]+0.01708[\theta]-0.001287 .[\mathrm{RH}]$ & 0.83 & 0.0096 & 0.0420 \\
$\mathrm{X}_{\max }$ & $-3.1442 .10^{11}+6.8025 .10^{9}[\mathrm{RH}]-3.587 .10^{7}[\mathrm{RH}]$ & 0.58 & 0.0464 & $1.414 .10^{9}$ \\
$\mathrm{C}_{\mathrm{LO}}{ }^{3}$ & $669.796-14.7004[\mathrm{RH}]+0.08164[\mathrm{RH}]+0.00821[\mathrm{RH}] \times[\theta]$ & 0.97 & 0.0001 & 0.9421 \\
$\mathrm{D}_{\mathrm{LO}}{ }{ }^{2}$ & $\mathrm{NS}$ & 0.73 & 0.0102 & 4.2249 \\
$\mathrm{C}_{\mathrm{LT}}{ }^{6}$ & $16.953-7.2021[\theta]+0.0799[\mathrm{RH}] \times[\theta]$ & 0.77 & 0.0055 & 4.0203 \\
$\mathrm{D}_{\mathrm{LT}}{ }^{7}$ & $10.3959-6.6947[\theta]+0.08014[\mathrm{RH}] \times[\theta]$ & 0.85 & 0.0014 & 0.0284 \\
$\mathrm{~V}_{\max }{ }^{2}$ & $-0.4921+0.01458[\theta+0.00564[\mathrm{RH}]$ & 0.57 & 0.0149 & 4.7659 \\
$\mathrm{~L}_{\mathrm{H} 2 \mathrm{O}^{8}} 8$ & $96.5572-0.8388[\mathrm{RH}]$ & 0.84 & 0.0015 & 0.5198 \\
$\mathrm{~T}_{\mathrm{U}-\mathrm{RIND}}{ }^{9}$ & $-15.146+0.1777[\mathrm{RH}]+0.125[\theta]$ & &
\end{tabular}

${ }^{1} \mu_{\max }=$ Maximum growth rate of $D$. hansenii $(/ \mathrm{d})$.

${ }^{2} \mathrm{X}_{\max }=$ Mean yeast maximum concentration (yeasts/g of DM).

${ }^{3} \mathrm{C}_{\mathrm{LO}}=$ Lactose maximal consumption rate on the rind ( $\mathrm{mmol} / \mathrm{kg}$ of $\mathrm{DM}$ per $\left.\mathrm{d}\right)$.

${ }^{4} \mathrm{D}_{\mathrm{LO}}=$ Lactose maximal decreasing rate in the core $(\mathrm{mmol} / \mathrm{kg}$ of $\mathrm{DM}$ per $\mathrm{d})$.

${ }^{5} \mathrm{C}_{\mathrm{LT}}=$ Lactate maximal consumption rate on the rind $(\mathrm{mmol} / \mathrm{kg}$ of $\mathrm{DM}$ per $\mathrm{d})$.

${ }^{6} \mathrm{D}_{\mathrm{LT}}=$ Lactate maximal decreasing rate in the core $(\mathrm{mmol} / \mathrm{kg}$ of DM per $\mathrm{d})$.

${ }^{7} \mathrm{~V}_{\max }=$ Maximal rate of deacidification ( $\mathrm{pH}$ unit/d).

${ }^{8} \mathrm{~L}_{\mathrm{H} 2 \mathrm{O}}=$ Relative weight loss $(\%)$.

${ }^{9} \mathrm{~T}_{\mathrm{U}-\mathrm{RIND}}=$ Thickness of underrind on $\mathrm{d} 14(\mathrm{~mm})$.

under consideration. A part of this loss corresponded to an evaporation of residual water from the rind to the atmosphere. It was supposed that the other part of this loss was due to the production of $\mathrm{CO}_{2}$ and evaporation of some volatile compounds.

Evolution of cheese appearance. The rind color of the cheeses provided information about the ripening and the growth of the microorganism. On $d 1$, rind color was homogeneously white and the cheese surface appeared moist and smooth. On d 14 (packaging), rind color was creamy and yeasts formed a layer close to 1 mm thick. On d 35, rind $\mathrm{pH}$ was $>7$, and Brevibacterium aurantiacum had grown, creating the orange color typical of the strain ATCC 9175.

The development of the thickness of the underrind, in relation to ripening time, provided information about the ripening level because the underrind is linked to proteolysis and lipolysis. This thickness $\left(\mathbf{T}_{\mathbf{U}}\right.$ RIND) became measurable when cheeses were packaged (on d 14) and was $2.5 \mathrm{~mm}$ for runs 5 and 6 (Table 1).

\section{Influence of Ripening Temperature and $\mathrm{RH}$ on Cheese Deacidification}

All the statistical tests were carried out using 95\% confidence levels $(P<0.05)$. Table 1 presents the overall results for the descriptors defined previously in relation to temperature and $\mathrm{RH}$ during ripening. Table 2 shows the associated quadratic models.

Influence of temperature and $\mathrm{RH}$ on Debaryomyces hansenii growth. Figure 4 (A and B) shows the response surfaces of the maximal specific growth rate $\left(\mu_{\max }\right)$ and the mean total numbers of $D$. hansenii
$\left(\mathrm{X}_{\max }\right)$ observed after $\mathrm{d} 14$ plotted against temperature and $\mathrm{RH}$.

Temperature and $\mathrm{RH}$ had statistically significant effects on $\mu_{\max }$, and the complex equation describing these effects included temperature and $\mathrm{RH}$ as individual terms and $\mathrm{RH}$ as quadratic ones (Table 2). This equation showed that these effects were linear for temperature and linear and quadratic for $\mathrm{RH}$, but the most important effect was due to temperature. This response surface indicated the presence of an optimal $\mathrm{RH}$ value (equal to $94.7 \%$ ), independent of the temperature values at which the maximum growth rate occurs. This optimum $\mathrm{RH}$ value is close to the center point value of $93 \%$. Indeed, at $\mathrm{RH}$ close to its optimum (93\%), when temperature increased from 8 to $12^{\circ} \mathrm{C}$, $\mu_{\max }$ value increased $34 \%$, and when temperature rose from 12 to $16^{\circ} \mathrm{C}$, it increased $15 \%$. The maximum value of $\mu_{\max }$, equal to $0.41 / \mathrm{d}$ (corresponding to a generation time of $1.7 \mathrm{~d}$ ), was obtained when the ripening conditions were $16^{\circ} \mathrm{C}$ and $94.7 \%$.

Between 8 and $16^{\circ} \mathrm{C}$, temperature did not change the maximal concentration of $D$. hansenii $\left(\mathrm{X}_{\max }\right)$ for 93\% RH. Only RH had a statistically significant quadratic effect on $\mathrm{X}_{\max }$. Similarly, this effect indicated the presence of a maximal $\mathrm{RH}$ value, equal to $94.8 \%$. The maximal $\mathrm{X}_{\max }$ value for a $\mathrm{RH}$ of $93 \%$ and a temperature of $16^{\circ} \mathrm{C}$ was equal to $9.2 \times 10^{9}$ yeasts/g of DM.

Influence of temperature and $\mathrm{RH}$ on carbon substrate evolutions. Disappearance of lactose in the core, because of its consumption by lactic acid bacteria and its diffusion from the core to the rind, was noted as $\mathrm{D}_{\mathrm{LO}}$. Temperature and $\mathrm{RH}$ did not have a significant effect on $\mathrm{D}_{\mathrm{LO}}$ at a $95 \%$ confidence level (Table 2). 
A

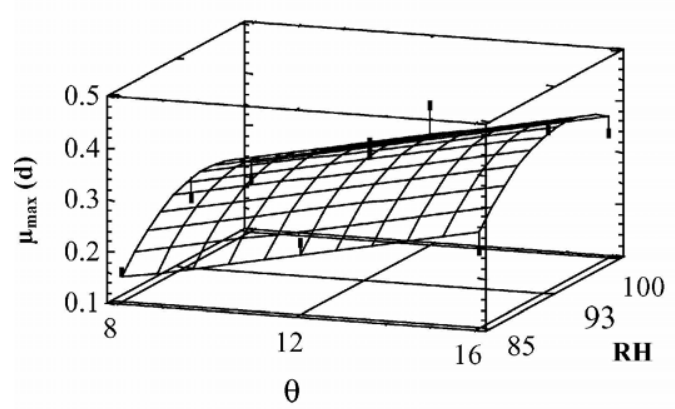

C

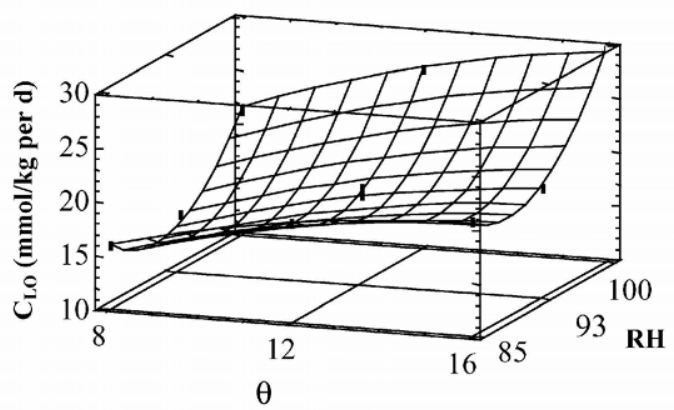

E

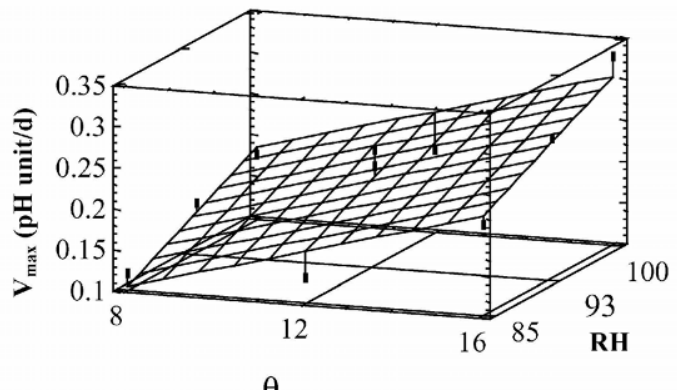

B

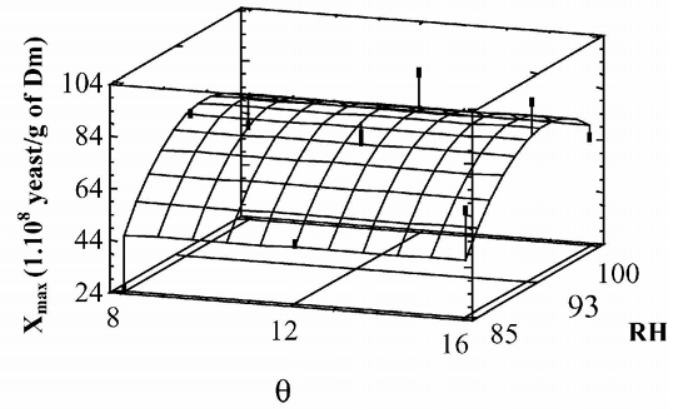

D

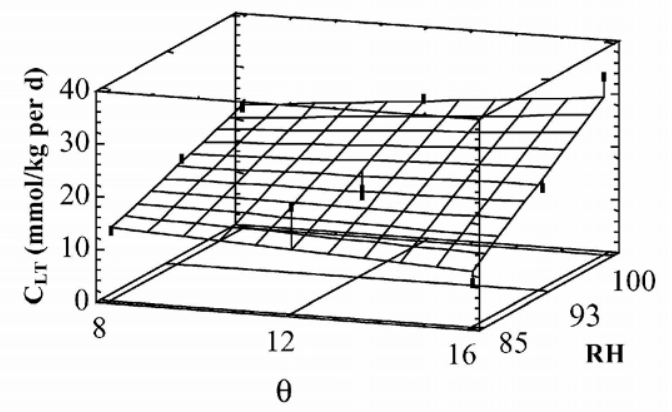

F

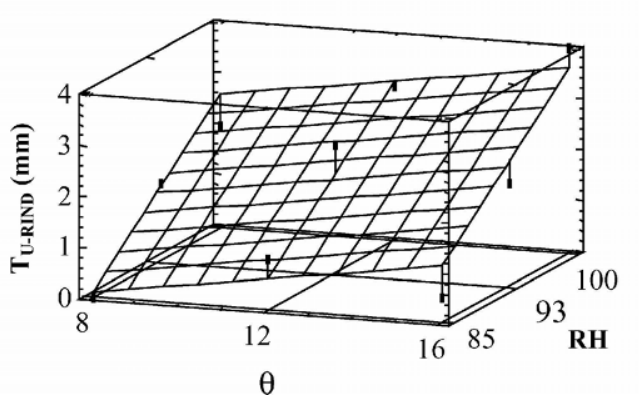

Figure 4. Estimated response surface plots of 6 deacidification descriptors as a function of temperature $(\theta)$ and relative humidity (RH). A) Maximum growth rate of $D$. hansenii $(/ \mathrm{d})\left(\mu_{\max }\right)$; B) mean yeast maximum concentration $\left(\times 1.10^{8}\right.$ yeast/g of DM) $\left(\mathrm{X}_{\max }\right)$; C) lactose maximal consumption rate on the rind $(\mathrm{mmol} / \mathrm{kg}$ per $\mathrm{d})\left(\mathrm{C}_{\mathrm{LO}}\right)$; D) lactate maximal consumption rate on the rind $\left.(\mathrm{mmol} / \mathrm{kg} \mathrm{per} \mathrm{d})\left(\mathrm{C}_{\mathrm{LT}}\right) ; \mathrm{E}\right) \mathrm{maximal}$ rate of deacidification $\left(\mathrm{pH}\right.$ unit/d) $\left.\left(\mathrm{V}_{\max }\right) ; \mathrm{F}\right)$ thickness of underrind on $\mathrm{d} 14(\mathrm{~mm})\left(\mathrm{T}_{\mathrm{U}-\mathrm{RIND}}\right)$.

Figure $4 \mathrm{C}$ shows the response surface of the lactose consumption rate $\left(\mathrm{C}_{\mathrm{LO}}\right)$ on the rind as a function of temperature and $\mathrm{RH}$. This equation (Table 2 ) included $\mathrm{RH}$ as an individual term, as an interactive term with ripening temperature and as a quadratic term. A minimum $\mathrm{RH}$ of $90 \%$ was found. $\mathrm{A}_{\mathrm{LO}}$ value, approximately equivalent to 85 and $93 \%$ for 12 and $16^{\circ} \mathrm{C}$, respectively, was obtained, reaching $20 \mathrm{mmol} / \mathrm{kg}$ of $\mathrm{DM}$ per $\mathrm{d}$. The maximal $\mathrm{C}_{\mathrm{LO}}$ value was obtained at $16^{\circ} \mathrm{C}$ and $100 \% \mathrm{RH}$ and was close to $30 \mathrm{mmol} / \mathrm{kg}$ of DM per d.

Ripening temperature and $\mathrm{RH}$ have the same effect on lactate disappearance in the core $\left(\mathrm{D}_{\mathrm{LT}}\right)$ and con- sumption on the surface $\left(\mathrm{C}_{\mathrm{LT}}\right)$. These values, $\mathrm{D}_{\mathrm{LT}}$ and $\mathrm{C}_{\mathrm{LT}}$, showed a greater sensitivity to temperature, with a linear effect, but an interaction between $\mathrm{RH}$ and temperature was also observed for high $\mathrm{RH}$ values (Figure 4D). Indeed, at $100 \% \mathrm{RH}, \mathrm{D}_{\mathrm{LT}}$ and $\mathrm{C}_{\mathrm{LT}}$ increased when the temperature increased from 8 to $16^{\circ} \mathrm{C}$. When the $\mathrm{RH}$ was equal to $85 \%$, the descriptor $\mathrm{C}_{\mathrm{LT}}$ increased to $35 \%$ when the temperature increased from 8 to $12^{\circ} \mathrm{C}$. However, this descriptor decreased when the temperature increased from 12 to $16^{\circ} \mathrm{C}$. At $93 \% \mathrm{RH}, \mathrm{C}_{\mathrm{LT}}$ decreased from 8 to $12^{\circ} \mathrm{C}$ but increased from 12 to $16^{\circ} \mathrm{C}$. At $100 \% \mathrm{RH}, \mathrm{D}_{\mathrm{LT}}$ followed the same evolution as $\mathrm{C}_{\mathrm{LT}}$. When $\mathrm{RH}$ was 85 or $93 \%, \mathrm{D}_{\mathrm{LT}}$ re- 
mained almost constant when the temperature increased. The maximal values were obtained for $16^{\circ} \mathrm{C}$ and $\mathrm{RH}$ of $100 \%$, equal to $33.6 \mathrm{mmol} / \mathrm{kg}$ of $\mathrm{DM}$ per $\mathrm{d}$ for $\mathrm{C}_{\mathrm{LT}}$ and $35.8 \mathrm{mmol} / \mathrm{kg}$ of $\mathrm{DM}$ per $\mathrm{d}$ for $\mathrm{D}_{\mathrm{LT}}$.

Influence of temperature and $\mathrm{RH}$ on $\mathrm{pH}$ evolution. Figure $4 \mathrm{E}$ shows the response surface of the maximal $\mathrm{pH}$ evolution rate $\left(\mathrm{V}_{\max }\right)$ as a function of temperature and $\mathrm{RH}$, both of which had highly significant linear positive effects. Indeed, for a given ripening temperature, cheese deacidification was better when $\mathrm{RH}$ increased. The same observation was obtained when $\mathrm{RH}$ was fixed and temperature increased. $\mathrm{V}_{\max }$ values increased when $\mathrm{RH}$ and temperature increased. The maximal $\mathrm{V}_{\max }$ value of $0.33 \mathrm{pH}$ unit/d was at $16^{\circ} \mathrm{C}$ and $100 \%$.

Influence of temperature and $\mathrm{RH}$ on cheese weight loss. The temperature did not have any effect on cheese $\mathrm{L}_{\mathrm{H} 2 \mathrm{O}}$ (Table 2). However, when the $\mathrm{RH}$ decreased the relative weight loss was greater. Indeed, $\mathrm{RH}$ had a significant negative linear effect on relative weight loss. The maximal relative weight loss rate was obtained at $85 \% \mathrm{RH}$ and was close to $26 \%$ of the initial cheese weight. This value was 2 times higher than that commonly obtained during soft cheese ripening (Reps, 1993).

Influence of temperature and RH on creamy underrind thickness. The response surface of underrind thickness $\left(\mathrm{T}_{\mathrm{U}-\mathrm{RIND}}\right)$ on $\mathrm{d} 14$ (packaging) as a function of temperature and $\mathrm{RH}$ is given in Figure $4 \mathrm{~F}$. The $\mathrm{T}_{\mathrm{U}-\mathrm{RIND}}$ was sensitive to $\mathrm{RH}$ and temperature, both of which had significant linear effects. On d 14, this thickness was equal to $2 \mathrm{~mm}$ at $8^{\circ} \mathrm{C}$ and $100 \% \mathrm{RH}$. The underrind thickened 50\% when the temperature increased from 8 to $12^{\circ} \mathrm{C}$. At $16^{\circ} \mathrm{C}$, this thickness was 2 times higher than the one observed at $12^{\circ} \mathrm{C}$. This descriptor increase was more moderate with $\mathrm{RH}$ increase.

\section{DISCUSSION}

Before ripening, $D$. hansenii grew most rapidly during the draining phase after salting, as previously described by Leclercq-Perlat et al. (1999), and its concentration was close to $5 \times 10^{8}$ yeasts/g of DM. The environmental conditions $\left(28 \pm 1^{\circ} \mathrm{C} ; \mathrm{RH}>98 \%\right)$ corresponding to this period could explain this observation because they were close to optimal for this species (Barnett et al., 1990).

During the first days of ripening (d 2 to 4 ), the $D$. hansenii growth rate $\left(\mu_{\max }\right)$ was strongly linked to the ripening temperature. The higher the temperature, the greater the $\mu_{\max }$. Only an RH close to the optimum (95 $\pm 1 \%$ ) allowed good growth of $D$. hansenii. For a $\mathrm{RH}$ of $85 \%$, the water flux between the cheese surface and the chamber atmosphere was very important (Simal et al., 2001). Thus the water loss from the cheese surface was fast, leading to surface drying of the cheese and inhibition of free water diffusion. Difficulties in the diffusion of the lactose and lactate substrates from the core to the surface and their accessibility to the yeast caused inhibition of $D$. hansenii growth. When the chamber RH was $>95 \%, D$. hansenii growth was lower because this yeast does not withstand high $\mathrm{RH}$ (Corry, 1987; Lesage-Meessen and Cahagnier, 1998). These RH effects also explain the mean yeast maximum concentrations $\left(\mathrm{X}_{\max }\right)$ for which higher values were observed for $\mathrm{RH}$ close to $95 \%$. The variations in $D$. hansenii growth due to the environmental conditions applied to the ripening chamber continued to be observed after packaging and until the end of ripening.

No significant effect of environmental conditions during ripening was observed on the lactose decrease in the cheese core. Two phenomena may explain this fact. First, Desmazeaud (1992) has shown that lactose is metabolized by lactic acid bacteria to lactate. Second, Leclercq-Perlat et al. (2000) have shown that lactose could diffuse from the core to the cheese surface where it might have been immediately consumed by $D$. hansenii. The reduction in water content paralleled the decrease in lactose consumption in the rind as well as in the core. As the $\mathrm{RH}$ in the ripening chamber is correlated with curd moisture (Hardy, 1997), RH probably had an important effect on the lactose diffusion (Fox et al., 1990). At 85\% RH, lactose diffusion to the rind was quickly stopped because of the lower cheese moisture, even though at a $\mathrm{RH}$ of $100 \%$, lactose was completely consumed on d 3. Moreover, the increase in the growth of $D$. hansenii with temperature could explain the enhancement of the lactose consumption rate. However, the interpretation of the response surface for lactose consumption was difficult because lactose metabolism took place during the first $6 \mathrm{~d}$ in the rind and the first $10 \mathrm{~d}$ in the core.

Increases in temperature and $\mathrm{RH}$ both promoted lactate consumption in the rind and its disappearance in the core. The consumption of this substrate due to $D$. hansenii growth was greater at higher temperatures. Soulignac (1995) has shown that $D$. hansenii used lactose and lactate at the same time but at different rates. The $\mathrm{RH}$ also played an important role. Indeed, at a $\mathrm{RH}$ of $100 \%$ the cheese moisture allowed a better diffusion of lactate from the core to the rind. But cheese moisture also has an important effect on enzymatic processes (Fox and McSweeney, 1996; Feeney et al., 2002). At $85 \% \mathrm{RH}$, lactate in the core was not able to diffuse to the surface and the yeast population decreased. This RH induced some stress conditions for D. hansenii, as shown by glycerol production (around 
$11 \mathrm{mmol} / \mathrm{g}$ of DM; data not shown). It is known that $D$. hansenii produces glycerol to protect itself against a saline or water stress (Gustafsson and Norkrans, 1976). However, an $\mathrm{RH}$ of $85 \%$ corresponded to an extreme growth limitation, and, after a few days of ripening, $D$. hansenii was not able to consume lactate. Consequently, the curd deacidification, which was mainly due to lactate consumption by $D$. hansenii (Leclercq-Perlat et al., 1999), stopped on d 6. The residual lactate concentration observed at $16^{\circ} \mathrm{C}$ was greater than that obtained at $8^{\circ} \mathrm{C}$. This observation can be explained by higher lactic acid bacteria activities at $16^{\circ} \mathrm{C}$ than at $8^{\circ} \mathrm{C}$ (Desmazeaud, 1992). It was confirmed by curd postacidification, which had been found to show an increase of lactate concentration in the cheese (Leclercq-Perlat et al., 1999). At $16^{\circ} \mathrm{C}$ and $85 \%$ $\mathrm{RH}$, lactate was not able to diffuse from the core to the rind due to the dryness of the cheese. For the other hygrometries, the rates of lactate consumption in the rind were enhanced by increasing the ripening temperature.

The deacidification rate of the cheese rind $\left(\mathrm{V}_{\max }\right.$, defined from $\mathrm{pH}$ evolution) increased with ripening temperature and $\mathrm{RH}$. This increase followed the decrease of lactate concentration. The greatest deacidification occurred when environmental conditions were most favorable for $D$. hansenii growth and when the moisture of the cheese was sufficient to permit carbon substrate diffusion. However, at the end of ripening (after $\mathrm{d} 20$ ), the $\mathrm{pH}$ remained close to 7.2 even though the lactate concentration continued to decrease. This fact could be explained by the amount of lactate still available in the cheese and by the buffering capacities of the cheese (Fox et al., 1990). According to these authors, the more water the cheese contained, the more carbon substrates were available. There are 2 possible explanations of $\mathrm{pH}$ constancy at the end of ripening: 1) the different processes of chemical balance (production of $\mathrm{NH}_{3}$ and aroma compounds) (Aldarf et al., 2002a, b) and 2) the cheese buffering capacity (Karahadian and Lindsay, 1985, 1987).

Weight loss was strongly correlated to a low $\mathrm{RH}$, which led to much dehydration of the cheese rind. Indeed, water, which represented an important part of weight loss, was vaporized from the surface toward the atmosphere, while at the same time water diffused from the core toward the surface (Simal et al., 2001). Conversely, high hygrometries led to lower drying rates. However, $\mathrm{RH}$ alone did not seem to explain the cheese weight loss, suggesting that a combination of external and internal conditions determined the drying rate (Le Graët and Brûlé, 1988; Luna and Chavez, 1992). Indeed, salt and moisture gradients were developed between the rind and the core of the cheese.
Hardy (1997) has shown that after d 5 to $6 \mathrm{NaCl}$ concentration in the rind was equal to that in the core. For this reason, the content of $\mathrm{NaCl}$ had not been followed, though the migrations of salt depend on the 2 parameters studied. According to Zorrilla and Rubiolo (1994), weight loss was due to dehydration and to salt redistribution to achieve an almost uniform salt distribution. But at packaging (d 14), cheeses ripened at $85 \% \mathrm{RH}$ had already lost a third of their initial weight. These products were very hard and dry (DM ratio close to 60 to $65 \%$ ) and were unfit for consumption. The cheese weight loss was also connected to temperature, but this had less of an effect than RH. According to Mollier's laws, for each RH the water loss was lower when chamber temperature decreased.

On $d 14$ (packaging), the thickness of the creamy underrind may be a good source of information about global proteolysis and lipolysis of the cheeses (Aldarf et al., 2002a, b). Gomes et al. (1998) and Gomes and Malcata (1998) have shown that temperature had a more important effect than $\mathrm{RH}$ for different proteolysis indexes and that it played a major role in the ripening of cheeses made with probiotic lactic acid bacteria. Following the lead of those researchers, we assumed that this thickness represented the global biochemical transformations of cheese constituents (proteolysis and lipolysis). The temperature and $\mathrm{RH}$ increases had an effect on creamy underrind thickening, which reached a maximum when the chamber conditions were $16^{\circ} \mathrm{C}$ and $100 \% \mathrm{RH}$; on $\mathrm{d} 14$ this thickness was equal to one-third of the cheese. However, there was no creamy underrind when the $\mathrm{RH}$ was $85 \%$. At a $\mathrm{RH}>90 \%$, Brevibacterium aurantiacum ATCC 9175 started to grow when the rind $\mathrm{pH}$ was close to 6.5 (Leclercq-Perlat et al., 2000). This bacterium growth takes place only when chamber $\mathrm{RH}$ is high (Bergère and Tourneur, 1992; Reps, 1993). Brevibacterium linens or B. aurantiacum is well known for its important exo- and endo-cellular proteolytic activities (Lecocq et al., 1996; Rattray and Fox, 1999), and D. hansenii does have endo-cellular proteolytic activity (Guéguen and Schmidt, 1992; Gobbetti et al., 1997). These two strains have no significant lipolytic activities. On d 14, the higher the ripening temperature and $\mathrm{RH}$, the greater the $B$. aurantiacum concentrations (results not shown), corresponding to a development of proteolysis and, consequently, a more abundant creamy underrind. As previously described in this study, at $100 \%$ $\mathrm{RH}$ a large number of $D$. hansenii cells could have lysed and released their enzymes. Moreover, under these conditions, the rind $\mathrm{pH}$ quickly rose to 7 (d 4 to 5 ), which could allow early growth of $B$. aurantiacum and, probably, proteolytic enzyme synthesis (Fox and Law, 1991; Han et al., 2003). On d 14 the underrind 
thickness reached $4 \mathrm{~mm} /$ face, and on $\mathrm{d} 42$ the cheeses were completely liquid.

\section{CONCLUSIONS}

Regardless of the temperature, a $\mathrm{RH}$ of $85 \%$ quickly stopped all the biochemical and physicochemical evolutions of the cheeses (microorganism growth, cheese deacidification, substrate diffusion, and substrate assimilation) and seemed to induce some $D$. hansenii cell defense mechanisms. In fact, the best ripening conditions to obtain an optimum between deacidification and cheese appearance quality appear to be a temperature of $12^{\circ} \mathrm{C}$ and an $\mathrm{RH}$ of 94 to $95 \%$.

In general, a rapid rate of development is sought to ensure a dense cover, to accelerate ripening, and to avoid possible contamination, as expressed by a more rapid reduction in the acidity of the cheese mass and by early installation of the acid-sensitive bacterial flora. As a parallel to $D$. hansenii, it would be interesting to study the behavior of other yeasts, such as Kluyveromyces lactis, which uses lactose initially and lactate only later, or Geotrichum candidum, which does not consume lactose at all. Such a study would provide elements for a more rational control of the ripening process, as its subsequent development is conditioned by yeast growth.

\section{ACKNOWLEDGMENTS}

The authors are deeply grateful to Benjamin Armenjon for his technical assistance throughout the study. Cristian Trelea's assistance with the statistical analyses is gratefully acknowledged. We also thank Suzette Tanis-Plant for her editorial advice.

\section{REFERENCES}

Abadias, M., N. Teixido, J. Usall, A. Benabarre, and I. Vinas. 2001. Viability, efficacy, and storage stability of freeze-dried biocontrol agent Candida sake using different protective and rehydration media. J. Food Prot. 64:856-861.

Agioux, L. 2003. Conception et validation d'un outil d'aide à l'estimation de l'état sensoriel des fromages en cours d'affinage. $\mathrm{pH} \mathrm{D}$, Institut National Agronomique, Paris-Grignon.

Aldarf, M., A. Amrane, and Y. Prigent. 2002a. Carbon and nitrogen substrates consumption, ammonia release and proton transfer in relation with growth of Geotrichum candidum and Penicillium camemberti on a solid medium. J. Biotechnol. 95:99-108.

Aldarf, M., F. Fourcade, A. Amrane, and Y. Prigent. 2002b. Growth model of Penicillium camemberti on a solid medium: A logitic model for substrate consumption and metabolite production. J. Biotechnol. 95: 99-108.

Barnett, J. A., R. W. Payne, and D. Yarrow. 1990. A Guide to Identifying and Classifying Yeasts. 4th ed. Cambridge University Press, Cambridge, UK.

Bergère, J. L., and C. Tourneur. 1992. The smear of cheese surface. Pages 127-163 in Les groupes microbiens d'intérêt laitier. J. Hermier, J. Lenoir, and F. Weber, ed. CEPIL, Paris, France.
Besancon, X., R. Ratomahenina, and P. Galzy. 1995. Isolation and partial characterization of an esterase (EC 3.1.1.1) from a Debaryomyces hansenii strain. Neth. Milk Dairy J. 49:97-110.

Bhowmik, T., and E. H. Marth. 1990. Role of Micrococcus and Pediococcus species in cheese ripening: A review. J. Dairy Sci. 73:859-866.

Bockelmann, W. 1997. Surface-ripened cheeses. Pages 121-132 in 5 th Cheese Symposium. Teagasc, Dublin, Ireland.

Bockelmann, W. 2002a. Development of defined surface starter cultures for the ripening of smear cheeses. Int. Dairy J. 12:123-131.

Bockelmann, W. 2002b. Development of smear cultures for semihard, soft and acid curd cheese. Lebensmittelindustrie \& Milchwirtschaft 123:93-99.

Choisy, C., M. J. Desmazeaud, J. C. Gripon, G. Lamberet, and J. Lenoir. 1997. La biochimie de l'affinage. Pages 86-105 in Le fromage. A. Eck and J. C. Gillis, ed. Tec \& Doc Lavoisier, Paris, France.

Corry, J. E. L. 1987. Relationships of water activity to fungal growth. Pages 51-92 in Food and Beverage Mycology. L. R. Beuchat, ed. Van Nostrand Reinhold, New York, NY.

Corsetti, A., J. Rossi, and M. Gobbetti. 2001. Interactions between yeasts and bacteria in the smear surface-ripened cheeses. Int. J. Food Microbiol. 69:1-10.

Cosentino, S., M. E. Fadda, M. Deplano, A. F. Mulargia, and F. Palmas. 2001. Yeasts associated with Sardinian ewe's dairy products. Int. J. Food Microbiol. 69:53-58.

Deiana, P., F. Fatichenti, and G. A. Farris. 1984. Use of lactic acid by strains of Debaryomyces hansenii under conditions of aerobic and anaerobic growth at different temperatures. Industria del Latte 20:33-41.

Desmazeaud, M. J. 1992. Les bactéries lactiques. Pages 49-62 in Les groupes microbiens d'intérêt laitier. J. Hermier, J. Lenoir, and F. Weber, ed. CEPIL, Paris, France.

Devoyod, J. J. 1990. Yeasts in cheese-making. Pages 228-240 in Yeast Technology. J. F. T. Spencer and D. M. Spencer, ed. Springer-Verlag, Berlin, Germany.

Eliskases-Lechner, F., and W. Ginzinger. 1995a. The bacterial flora of surface-ripened cheeses with special regard to coryneforms. Lait 75:571-583.

Eliskases-Lechner, F., and W. Ginzinger. 1995b. The yeast flora of surface-ripened cheeses. Milchwissenschaft 50:458-462.

Feeney, E. P., T. P. Guinee, and P. F. Fox. 2002. Effect of pH and calcium concentration on proteolysis in Mozzarella cheese. J. Dairy Sci. 85:1646-1654.

Ferchichi, M., D. Hemme, and C. Bouillanne. 1986. Influence of oxygen and $\mathrm{pH}$ on methanethiol production from L-methionine by Brevibacterium linens CNRZ 918. Appl. Environ. Microbiol. $51: 725-729$

Fleet, G. H. 1990a. Food spoilage yeasts. Pages 124-166 in Yeast Technology. J. F. T. Spencer and D. M. Spencer, ed. SpringerVerlag, Berlin, Germany.

Fleet, G. H. 1990b. Yeasts in dairy products. J. Appl. Bacteriol. 68:199-211.

Fox, P. F., and A. J. R. Law. 1991. Enzymology of cheese ripening. Food Biotechnol. 5:239-262.

Fox, P. F., J. Law, P. L. H. McSweeney, and J. Wallace. 1993. Biochemistry of cheese ripening. Pages 421-438 in Cheese: Chemistry, Physics and Microbiology. Vol. 1. P. F. Fox, ed. Elsevier Applied Science, London, UK.

Fox, P. F., J. A. Lucey, and T. M. Cogan. 1990. Glycolysis and related reactions during cheese manufacture and ripening. CRC Crit. Rev. Food Sci. Nutr. 29:237-253

Fox, P. F., and P. L. H. McSweeney. 1996. Proteolysis in cheese during ripening. Food Rev. Int. 12:457-509.

Gavrish, E. Y., V. I. Krauzova, N. V. Potekhina, S. G. Karasev, E G. Plotnikova, O. V. Altyntseva, L. A. Korosteleva, and L. I. Evtushenko. 2004. Three new species of brevibacteria, Brevibacterium antiquum sp. nov., Brevibacterium aurantiacum sp. nov., and Brevibacterium permense sp. nov. Microbiol. 73:218225. 
Gobbetti, M., A. Corsetti, E. Smacchi, M. de Angelis, and J. Rossi. 1997. Microbiology and biochemistry of Pecorino Umbro cheese during ripening. Ital. J. Food Sci. 9:111-126.

Gomes, A. M. P., and F. X. Malcata. 1998. Development of probiotic cheese manufactured from goat milk: Response surface analysis via technological manipulation. J. Dairy Sci. 81:1492-1507.

Gomes, A. M. P., M. M. Vieira, and F. X. Malcata. 1998. Survival of probiotic microbial strains in a cheese matrix during ripening: simulation of rates of salt diffusion and microorganism survival. J. Food Eng. 36:281-301.

Gripon, J. C. 1993. Mould-ripened cheeses. Pages 111-136 in Cheese: Chemistry, Physics and Microbiology. Vol. 2. P. F. Fox, ed. Chapman \& Hall, London, UK.

Guéguen, M., and J. L. Schmidt. 1992. Les levures et Geotrichum candidum. Pages 165-219 in Les groupes microbiens d'intérêt laitier. J. Hermier, J. Lenoir, and F. Weber, ed. CEPIL, Paris, France.

Gustafsson, L., and B. Norkrans. 1976. On the mechanism of salt tolerance: Production of glycerol and heat during growth of $D e$ baryomyces hansenii. Arch. Microbiol. 110:177-183.

Han, B.-Z., Y. Ma, F. M. Rombouts, and M. J. Robert Nout. 2003. Effects of temperature and relative humidity on growth and enzyme production by Actinomucor elegans and Rhizopus oligosporus during sufu pehtze preparation. Food Chem. 81:27-34.

Hardy, J. 1997. Water activity and salting cheeses. Pages 62-83 in Le fromage. A. Eck and J. C. Gillis, ed. Tec \& Doc Lavoisier, Paris, France.

Hardy, J., J. Scher, H. E. Spinnler, E. Guichard, and J. C. Gripon. 2000. Physical and sensory properties of cheese. Pages 447-473 in Cheesemaking: From Science to Quality Assurance. A. Eck and J. C. Gillis, ed. Intercept Limited, Andover, UK.

Jakobsen, M., and J. Narvhus. 1996. Yeasts and their possible beneficial and negative effects on the quality of dairy products. Int. Dairy J. 6:755-768.

Karahadian, C., and R. C. Lindsay. 1985. Factors controlling texture in mould surface-ripened cheeses. J. Dairy Sci. 68:92-93.

Karahadian, C., and R. C. Lindsay. 1987. Integrated roles of lactate, ammonia, and calcium in texture development of mould surfaceripened cheese. J. Dairy Sci. 70:909-918.

Klein, N., A. Zourari, and S. Lortal. 2002. Peptidase activity of four yeast species frequently encountered in dairy products: comparison with several dairy bacteria. Int. Dairy J. 12:853-861.

Le Graët, Y., and G. Brûlé. 1988. Migration of macro and oligoelements in a soft cheese like Camembert. Lait 68:219-234.

Leclercq-Perlat, M. N., J. L. Bergère, and G. Corrieu. 1995. Development of a method for enumeration of yeast cells on the surface of soft cheese. Lait 75:151-168.

Leclercq-Perlat, M. N., A. Oumer, J. L. Bergère, H. E. Spinnler, and G. Corrieu. 1999. Growth of Debaryomyces hansenii on a bacterial surface-ripened soft cheese. J. Dairy Res. 66:271-281.

Leclercq-Perlat, M. N., A. Oumer, J. L. Bergère, H. E. Spinnler, and G. Corrieu. 2000. Behaviour of Brevibacterium linens and Debaryomyces hansenii as ripening flora in controlled production of smear soft cheese from reconstituted milk: growth and substrate consumption. J. Dairy Sci. 83:1665-1673.

Lecocq, J., and M. Guéguen. 1994. Effects of $\mathrm{pH}$ and sodium chloride on the interactions between Geotrichum candidum and Brevibacterium linens. J. Dairy Sci. 77:2890-2899. Lecocq, J., M. Guéguen, and O. Coiffier. 1996. The importance of the association between Geotrichum candidum and Brevibacterium linens in the ripening of cheeses with washed rind. Sci. Aliments $16: 317-327$

Lenoir, J., G. Lamberet, J. L. Schmidt, and C. Tourneur. 1985. Control of the cheese bioreactor. Biofutur 41:23-50.

Leon-Gonzalez, L. P. Ponce De, W. L. Wendorff, B. H. Ingham, J. J. Jaeggi, and K. B. Houck. 2000. Influence of salting procedure on the composition of Munster-type cheese. J. Dairy Sci. 83:1393-1401.
Lesage-Meessen, L., and B. Cahagnier. 1998. Mécanismes d'adaptation des micromycètes aux activités de l'eau réduite. Pages 1935 in Moisissures des aliments peu hydratés. B. Cahagnier, ed. Ch. 2: Collection Sciences et Techniques Agro-Alimentaires. Lavoisier Tec \& Doc, Paris, France.

Luna, J. A., and M. S. Chavez. 1992. Mathematical model for water diffusion during brining of hard and semi-hard cheese. J. Food Sci. 57:55-58.

Nakase, T., M. Suzuki, and H. J. Phaff. 1998. Genus Debaryomyces. Pages 157-173 in The Yeasts: A Taxonomic Study. 4th ed. C. P. Kurtzman and J. W. Fell, ed. Elsevier, Amsterdam, The Netherlands.

Nunez, M., A. M. Guillen, M. A. Rodriguez-Marin, A. M. Marcilla, P. Gaya, and M. Medina. 1991. Accelerated ripening of ewes' milk Manchego cheese: The effect of neutral proteinases. J. Dairy Sci. 74:4108-4118.

Petersen, K. M., S. Westall, and L. Jespersen. 2002. Microbial succession of Debaryomyces hansenii strains during the production of Danish surface-ripened cheeses. J. Dairy Sci. 85:478-486.

Piton, C. 1988. Evolution de la flore microbienne de surface du Gruyère de Comté au cours de l'affinage. Lait 68:419-434.

Ramet, J. P. 2000. Comparing ripening technology of the various types of cheese. Pages 418-446 in Cheesemaking from Science to Quality Assurance. A. Eck and J. C. Gillis, ed. Lavoisier Publishing, Paris, France.

Rattray, F. P., and P. F. Fox. 1999. Aspects of enzymology and biochemical properties of Brevibacterium linens relevant to cheese ripening: A review. J. Dairy Sci. 82:891-909.

Reps, A. 1993. Bacterial surface-ripened cheeses. Pages 137-172 in Cheese: Chemistry, Physics and Microbiology. Vol. 2: Major Cheese Groups. P. F. Fox, ed. Chapman \& Hall, London, UK.

Roostita, R., and G. H. Fleet. 1996. Growth of yeasts in milk and associated changes to milk composition. Int. J. Food Microbiol. 31:205-219.

Schepers, A. W., J. Thibault, and C. Lacroix. 2000. Comparison of simple neural networks and nonlinear regression models for descriptive modelling of Lactobacillus helveticus growth in $\mathrm{pH}-$ controlled batch cultures. Enzyme Microb. Technol. 26:431-445.

Schmidt, J. L., C. Graffard, and J. Lenoir. 1979. Biochemical aptitudes of yeasts isolated from Camembert cheese. I. Preliminary studies. Lait 59:142-163.

Seiler, H., and M. Busse. 1990. The yeasts of cheese brines. Int. J. Food Microbiol. 11:289-304.

Seiler, H., and M. Kummerle. 1998. Yeasts species in the environment of dairy production lines. Pages $173-177$ in Yeasts in the Dairy Industry: Positive and Negative Aspects. Proceeding of Copenhagen, Denmark. Int. Dairy Fed., Brussels, Belgium.

Simal, S., E. S. Sanchez, J. Bon, A. Femenia, and C. Rossello. 2001. Water and salt diffusion during cheese ripening: Effect of the external and internal resistances to mass transfer. J. Food Eng. 48:269-275.

Soulignac, L. 1995. Propriétés des levures fromagères: influence des substrats carbonés utilisés sur leurs capacités à désacidifier les caillés et à produire des composés d'arôme. Thèse de Docteur, Institut National Agronomique, Paris-Grignon, France.

Valdes-Stauber, N., S. Scherer, and H. Seiler. 1996. Identification of yeasts and coryneform bacteria from the surface microflora of brick cheeses. Int. J. Food Microbiol. 34:115-129.

van den Tempel, T., and M. Jakobsen. 2000. The technological characteristics of Debaryomyces hansenii and Yarrowia lipolytica and their potential as starter cultures for production of Danablu. Int. Dairy J. 10:263-270.

Vassal, L., V. Monnet, D.L. Bars, C. Roux, and J. C. Gripon. 1986. Relation between $\mathrm{pH}$, chemical composition and texture of Camembert cheese. Lait 66:341-351.

Wouters, J. T. M., E. H. E. Ayad, J. Hugenholtz, and G. Smit. 2002. Microbes from raw milk for fermented dairy products. Int. Dairy J. 12:91-109.

Zorrilla, S. E., and A. C. Rubiolo. 1994. Fynbo cheese $\mathrm{NaCl}$ and $\mathrm{KCl}$ changes during ripening. J. Food Sci. 59:972-985. 